\title{
Is There an Igbo-African Logic?
}

\author{
Ogugua Paul Ikechukwu, Ogugua Ifunanya Clara \\ Department of Philosophy, Nnamdi Azikiwe University, Awka, Nigeria \\ Email: paiykeo@yahoo.co.uk, ifunanyaoguguap@yahoo.com
}

Received 24 October 2014; accepted 26 March 2015; published 27 March 2015

Copyright (C) 2015 by authors and Scientific Research Publishing Inc.

This work is licensed under the Creative Commons Attribution International License (CC BY).

http://creativecommons.org/licenses/by/4.0/

(c) (i) Open Access

\section{Abstract \\ This paper is not concerned with the possibility of Igbo-African Logic, it asserts that there is. It emphasizes that there could not be comprehension an understanding of relations and meaning respectively without logic. The paper goes on to capture what the nature of Igbo-African Logic is.}

\section{Keywords}

Philosophy, Ontology, Logic, Language, Igbo, African

\section{Introduction}

Metaphysics is the rock bottom, and foundation of different theories in life. Every theory's truth or falsity depends on the type of metaphysics on which it is anchored. Metaphysics is according to Alpern "the study of reality, of that which does not appear to our senses, of truth in the absolute sense, ...” (Onyewuenyi, 1983) From the traditional classification of philosophy, metaphysics falls within the real aspect of philosophy, thus metaphysics is related so much to epistemology which is located within rational philosophy and both are sisters. How are they related? Metaphysics studies being from the point of view of existence while epistemology studies being from the point of view of cognition. Logic itself is located within epistemology; hence is primarily an epistemological tool though it serves philosophy as a whole.

It is a truism that ontology remains the heart of metaphysics, and that ontology is relative to peoples and at times groups. Why is it so? Simply put, it is because every culture understands being differently. This is the rationale for thinking of African ontology, western ontology, Asian or Chinese ontology, etc. Or else why did M. V. O. Quine hold that "reference is inscrutable"? If actually it is so, then it must have a "consequence for ontology" (Halymn, 1984). That automatically means that it must equally have an effect on epistemology and logic as well. This is so because our understanding and sensibility constitute the limits within which we can affirm certain things about reality as what we assume to exist is very relative to the theory and language we bring to bear on that thing and on the very situation in question. Because we can rightly talk of African philosophy as distinct from western philosophy, we can at the same time talk of African epistemology and logic as being distinct from 
Western, Asian, or Chinese logic and epistemology.

It is not our intention to get ourselves entangled in "ignornatiaelenchi" as our philosophers did in the past, debating whether African philosophy exists or not? Irrespective of the position of the Purists who want to maintain the purity and integrity of philosophy, we work with the premise that there is Igbo-African logic. That means we have moved ahead of Udo Etok who wrote on the "Possibility of African Logic" in The Third Way in African Philosophy. As we ride on the crest of the success story of African philosophy, in spite of pockets of resistance at some quarters, we have to wade through the skirmishes ignited by the heavy debate with regard to the existence and nature of African Philosophy. Logic, we all know, is the most rigorous aspect of the philosophical enterprise as it lies at the core of philosophy. We make bold to show that there is logic in Igbo language and that there is Igbo-African logic. How do we go about this arduous task? We are going to re-visit the universal nature of philosophy, and in the same vein, universal nature of logic and then go on to show that formalized or symbolic logic is equally possible within the Igbo language.

\section{Philosophy: A Universal Enterprise?}

Philosophy is like the proverbial elephant which the six blind men of Hindustan observed and experienced and came out with different views, yet, they all talked of the same entity. Philosophy could be viewed from different sides, it could be defined etymologically as love of wisdom, a world-view of a people; an attitude towards life, this is more experiential; or as a theoretic discipline, here we have the technical or scholar's perception of philosophy. The first three views suggest that philosophy is a universal enterprise while the last view suggests that it can become a universal enterprise with training in the philosophic enterprise.

The philosophic enterprise is not strictly speaking, academic; hence it is a multi-faceted enterprise with degrees of ascension and acceleration in the journey of thought, wonder and meditation. It will be asking or expecting too much from every people to have at once a philosophy that is purely academic, theoric at the level of mathematics or physics; for philosophy has always grown out of a people's understanding of the meaning of realities in their world-view and culture. Ask yourself, did Plato's and Aristotle's philosophies not bear semblance to Greek's culture and tradition? Did ancient philosophies not express a pot-pourri of literary pieces in the form of conversations and treatises? The truth is that without the culture of a people their philosophy cannot be birthed. Okolo, C. B. observed that,

The materials of culture are objects or materials for philosophic reflections. The philosopher cannot think, interpret and find meaning in a vacuum. This he does through his particular culture.

He continued:

African philosophy... emerges out of the culture as the African philosopher critically reflects on the language, religion, history, works of art, folklore, idioms, collective beliefs, etc. of the African people. (Okolo, 1987)

Philosophy is birthed in any place when people of that place or in the place essay their best through critical thinking to arrest challenges and problems of that milieu. African philosophy is not different, it is as a result of the African grasping the realities of the African world via the epistemic and logical prisms and processes. The Purists may not feel at ease agreeing that philosophy is tied to culture as they tilt more towards forms, symbols, or philosophy as a theoretic discipline; but there has not been any philosophy be it Chinese, Indian, British or American philosophy which has not been tied to a culture.

There is no doubt that philosophy is a universal discipline. Udo Etuk writes "Philosophy is a universal discipline only in the sense that the quest for the understanding of life is something that every human group undertakes." (Oladipo, 2002) Although philosophy is universal, it is not boundless, there are boundaries for every people will undertake the quest for understanding the meaning of realities and human existence differently as they have different worldviews. It does seem too that this relativity will affect logic irrespective of the fact that logic is a science of pure form. Logic does not pay attention to either truth or matter or declarative sentences as such but one would expect the difference to lie in and with natural logic and not with artificial logic. It will be out of place for one to expect Igbo-African logic to be at the level of sophistication as the formalization and abstraction of thoughts, making the study of forms in logic removed from the realities of thought and language; that is, being myopic as to suffer from mania for symbols. The truth is that not even an American, nor Briton or 
any European not tutored in academic logic or precisely symbolic logic can understand how "modus ponens" or/and "modus Tollens" work(s). Do you know that not every academic philosopher can understand the treatise of Whitehead and Russell on logic - that is the Principia Mathematica? A pivotal question facing us now, is abstract logic that is study of forms in logic all that there is to logic? At this level, logic can be universalized; as it has to do with symbolization. The existence of logics tends to show that it will not be out of place to have IgboAfrican logic; this logic is sound but it has to concern itself with matters of practical import. It is a logic serving the purposes of language, law, morality, habit, etc. In short, it is a tool for articulation, appreciation and comprehension of Igbo-African realities.

\section{Logic: With or/and without Boundaries?}

Symbolic logic, formalized logic or mathematical logic is without boundaries, for it is like arithmetic or mathematics. But natural logic is with boundaries as it has to do with practical activities in life. On this score, we posit the existence of logic in every culture. It is sound therefore to talk of Igbo-African logic for logic is concerned with method of knowing and that is not only the Western method of knowing that is available. Paul Feyerabend held that "knowledge is obtained from a proliferation of views rather than from the determined application of a preferred ideology." (Feyerabend, 1975) It will be too naïve for one to hold that everybody must see reality and/or know reality from one prism alone. Feyerabend expressed the reality of variety of method thus: It is clear, then, that the idea of a fixed method, or a fixed theory of rationality, rests on too naïve a view of man and his social surroundings (Feyerabend, 1975).

Western logic has not got and cannot have a monolithic claim of knowledge; for every method has its limits; hence to give a comprehensive view, there is need for complementarity of views of methods. Every method is good in its own respect more precisely with a particular background, language or people. For example, in some languages, the adjective comes before the noun while in some others it comes after the noun. In Latin language for instance we talk of "homo faber" meaning the working man.

In order to achieve our objective of showing that logic is natural to Igbo-Africans, we have to show that logic is related to language. Every language belongs to a culture and every culture belongs to a people. Logic makes language possible, language expresses culture, and since culture presupposes the existence of logic, logic is central in any culture. On account of the connection between and among these concepts one would discover without much ado that logic is fundamental to African world-view. Uduma got this glimpse, he holds that

The cultural experiences of a people cannot be meaningful unless they are organized or co-ordinated in language, an activity which itself presupposes a logical ability, logic and language are fundamental or central to organizing reality and thus a characteristic of all human societies. (Unah, 1998)

There is no doubt that there is a relationship among elements of these triads: logic, truth and thought, and there is a relationship equally between logic and language. As we follow this path of explanation, we will be gradually led to the nature of Igbo-African logic.

Logic is the art and science of reasoning which aids us in production of valid thought. What does it reason about? It reasons about Reality, with the aid of consciousness in the bid to produce knowledge. Truth is to say of what is that it is. It could be said to mean equally correspondence of something to a fact, the consistency of something to a fact or a set of principles, it should be said to being true to the case. Thought according to Webster Dictionary (1980) is the act or process of thinking; reflection; meditation; cognition; It has to do with the ability, or capacity or power to reason. Logic and thought are related and as such meet at the universe of truth. Little wonder, we talk of logic of thought and truth; and thought of logic and truth. Vice versa we can talk of the truth of logic and thought. In the triadic triangle which is universal we have shown that logic is common to every rational person; as he makes use of mind to think thought.

We have shown that logic must be about something, for only something or somebody can be known; so it is related to the triadic triangle of reality, knowledge and consciousness. In the same vein, logic too, is related to the universic triad of language, meaning and understanding; hence one can talk of logic of language, meaning and understanding, because the universes of language and understanding meet at the universe of meaning without entering into the universes of language and understanding. Ogugua made it too clear that many scholars have been in error of mistaking comprehension for understanding. He states that comprehension has to do with relations between and/or among concepts, while understanding has to do with the meaning of something or concept 
(Ogugua, 2003). In pursuit of our objective, we have to examine the relationship between logic and language; so as to lay proper foundation which will make it easy for us to discover or unveil logic in our ordinary and natural language, which is the tool we have to communicate meaning.

\section{Logic and Language: Any Connection?}

Language has to do with speech, and man is the only creature nature endowed with the faculty for concept formation. Other animals can only utter or make sounds; hence only man is associated with logic which is the science of the law or principles of thought. The relationship between both concepts can be traced from the Greek words "Logikos" and “logos”. The Greek word “logos” means word, reason, or in an extended sense, discourse. "Logikos" means "belonging to speech or speaking” or "belonging to the reason or rationale” (Lidell-Scott, 1968). The egg and chicken controversy is analogous to the language and thought controversy but Uduma makes bold to state that "Thought is prior to language; but thought can make no progress without embodying itself in language.” (Unah, 1998) Language has been discovered to have played great role in the development of logic throughout the ages. Words make up the "arsenals" or tools of a language, hence are "arches" for the mind and "fortresses" of thought. Logic concerns itself more with words which fix thought and control meaning. John R. Carroll did not miss this point, he states "Logic is not then primarily a tool of discovery, but rather an aid to understanding and clarification.” (Carroll, 1971) To do this each people will bring in their experience of life and history, there is no how their culture and world-view will be totally excluded. Mellone glimpsed at what we have just said and observed that "Logic has to consider language; but only so far as differences of expressions in language are the embodiment of differences of type in the process of thought.” (Mellone, 1902) Ontology is relative, likewise "culture" and world-view hence language which identifies a people is equally relative. Language differs as each group (people) has the onus of building their language structures, and has to design how nature should be broken down to elements which are put into sentences. Nze observed:

As soon as we have an idea, there is an irresistible urge to sheath; in a word. Our thought is purely inward and in a sense abstract; the word has an external existence as a symbol, and of course, is a thing of sense. (Nze, 1998)

Language is a tool of reason. Logic considers language as a tool of reasoning and wants to use language correctly so as to avoid obstacles to correct thinking. Logic then involves a study of language; as language according to Werkmeinster "alone gives us access to the experiences and insights of our fellowmen.” (Werkmeister, 1968) That shows that to know and master a language entails to an extent to know the rules of logic in that language as logic does not concern itself with a set of rules which are externally related to a language but is itself contained and subsumed in a language. As each language expresses its thoughts in its own way so as to have the desired and required euphony, logic ensures that the principles of valid reasoning and argument are employed to avoid crooked thinking.

Language no doubt asserts a kind of influence on the mind of a people; it provides them with an outline map for perceiving the world and realities therein. This map is fundamental to their thought processes. Is it difficult to see the relationship between grammatical structure of a language and our thought or thinking structure? Language gives us the scheme of our ways of thinking; and thought remains the common background on which persons meet in the bid to have common and mutual understanding. Although language gives thought a cloak, that means it canalizes it, we need not conclude that without language thoughts are not meaningful. Thoughts are meaningful in private minds, but we need language which is a social product in conveying our thoughts; and as such too logic to ensure that meaning of our thoughts is not lost; and avoid our language being a hindrance to our getting at the real meaning of what is said as language can be the source of confusion or misunderstanding by fixing our emotions or even enroping our tradition therein.

\section{Nature of Igbo-African Logic}

Logic is the art and science of the rules, principles and laws which is concerned with the clarification of language, aimed at correct reasoning. Why? It is because language could be used as a tool for bewitchment; to avoid fallacies of formal, linguistic, material and circumstantial nature. Logic ensures that one has an ordered, balanced and systematic facility. Uduma states: 
Without logic, therefore, the possibility of one consciously performing basic human functions including linguistic functions becomes questionable. The reason for this is because the capacity to organize reality intelligibly by means of language is made possible by logic. (Unah, 1998)

The fact that logic is a primary tool of language used to organize the world shows that logic is a natural disposition of every homo sapiens; as such logic is an element of culture. So the logic of a people is not only discernable but discoverable in their language; that is why it is related to their metaphysics, strictly speaking, ontology and worldview. Let us quote Alpern again, he states:

Metaphysics by the very definition that it is the study of reality, of that which does not appear to our senses, of truth in the absolute sense, is the groundwork of any theory concerning all phases of human behavior... (Onyewuenyi, 1983)

It is with regard to logic found in a people's language that we primarily talk of Igbo-African logic. (That does not suggest that we cannot with a dint of hardwork symbolize Igbo logic or put it in forms. It can be formalized). Enyimba consents that there is logic in the African context and said:

One's behaviour and attitude can be described as logical or illogical, reasonable or unreasonable, rational or irrational. This goes to show that behaviour also falls under the scope of logic ... because the way one thinks largely determines the way he behaves. (Enyimba, 2003)

Logic is natural to every rational man; so it is a fundamental attribute of the human person or else how does one organize his experiences? No doubt, logic is the intrinsic element which constitute these experiences into a unified whole. This "intrinsic constitutive element" lies beneath or pre-ontological and pre-theoretical conception of logic. No man can understand being without logic. It is not just possible; for logic offers an explanation for not only the orderly nature of being but for its intelligibility as well. Little wonder C. S. Momoh poignantly expressed:

In everyday usage of natural language we talk of a person as being logical if he is reasonable, sensible and intelligent; if he can unemotionally and critically evaluate evidence or a situation; if he can avoid contradiction, inconsistency and incoherence or if he can hold a point of view argue for or from it, summon counterexamples and answer objections. (Momoh, 2003)

Some scholars feel more comfortable accepting that African logic has to do with natural logic and not with artificial logic. We do not seem to quite agree with them, for logic concerns itself primarily with ordinary language and not any form of logistic language. Moreso, logic deals with artificial language. So to hold like Horton and Levy Bruhl that "Africans are prelogical, primitive and lacking in logic" (Hallen, 1977) is not only false but exposition of ignorance by the nature and dimensionality of logic. Why do we hold this view? It is because, logic remains the intellectual sheet anchor of a people's appreciation of life. Every language has its own logic. Ijiomah argues:

The raw data for logic is what a people think is the relationship among realities and it is only when these are available that what should be the case is established. (Ijiomah, 1995)

Rene Descartes observes too that:

... the power of judging aright and of distinguishing truth from error, which is properly what is called good sense or reason, is by nature equal in all men; and that the diversity of our opinions consequently does not arise from some being endowed with a larger share of reason than others, but solely from this, that we conduct our thoughts along different ways and do not fix our attention on the same objects. (Bronstein, 1947)

Every people are logical, hence have their logic; which is connected to their ordinary language. Or else why is it we do not talk in an absurd or/and illogical manner? Logicians are interested in language; we mean ordinary language. In his article "A Plea for Excuses" J. L. Austin stated clearly the reasons for this interest in ordinary language. For Ludwig Wittgenstein who defined philosophy as an attempt or effort to avoid being bewitched with the use of language, logic has a place in language. Logic's place is located in the postulation, pursuit and realization of the logical ideal. John Locke expresses implicitly the essentiality of logic thus:

Language being the great conduit whereby men convey their discoveries, reasonings, and knowledge from 
one to another; he that makes an ill use of it though he does not corrupt the functions which are in things themselves; yet he does, as much as in him lies break or stop the pipes whereby it is distributed to the public use and advantage of mankind. (Unah, 1998)

In as much as logic does not aid correct thinking directly, it no doubt aids in quickening our "sense" of preparation, caution and assessment of both good and bad reasoning. Uduma agrees thus:

Arguably therefore without logic the possibility of one consciously performing basic human functions, particularly linguistic ones, is doubtful and uncertain. (Unah, 1998)

There is no gainsaying the fact that logic would have no content and form without language, and that language will be a dream, quite impossible without logic. The relation between both is strong. There is logic in IgboAfrican language. Tomassi did observe: ... logic is not really a matter of memorizing and applying daunting mechanical rules but is rather a reflective study of how well we can all naturally reason at our very best.

The rules, principles and laws of logic are quite evident in our mode of thought; it is our present preoccupation to show that there is logic in Igbo language.

\section{What Is Igbo-African Logic Like?}

It is a truism that reason is a universal characteristic of man, man thinks thought and thought is never about nothing, it must be of something or somebody, likewise knowledge. This points to the fact that knowledge is perspectival, likewise thought hence particularististic; as it is shaped by problems, experiences and challenges of particular periods of time.

Some thinkers erroneously think and believe that Igbo-Africans do not have a philosophymoreso logic because Igbo culture is a pre-literate culture. They forget that not every culture is literate one. Moreover IgboAfrican culture is that of "vetera et novo" both old and new mixed, so what we have is Igbo-African logic and not modern or traditional Igbo-African logic. You can see without much ado that literacy cannot be a criterion for assessing whether a culture has a philosophy or not, for no group could have existed for any length of time without the ability to reason and think. Man's ability to make use of language presupposes without doubt the presence of a fundamental logical disposition. There is evidence of logic in every culture even in predominantly old ones, for the origin of logic is associated with the grammar of language and in the very way discussion and argument are held in the said language. Berkeley did sense this for he said "the communicating of ideas is not the chief and only end of language, as is commonly supposed. There are other ends, ..." (Alston, 1964) And Oladipo says of Wiredu's perception of this fact that:

These people are capable of fundamental reflection on man, society and culture. They do not merely recite the folk philosophies of their communities, they are able to subject these philosophies to "criticism and modification”. More than this, they support their views or ideas with reasons or arguments. (Oladipo, 2002)

There is no doubt that the ordinary language may not be able to be used in making subtle analysis and distinctions. This then compels some thinkers to hold that symbolic logic with its artificial logic is of prime importance. Uduma captures this thus:

The point being that for many philosophers the artificial language of symbolic logic is considered to be more perfect than the natural language, hence they try to formulate their theories in such artificially regulated logistic languages. (Unah, 1998)

On the camp are scholars, more precisely philosophers who do not deny the scientific nature and value of the logistic calculi but who do not think it is a "sine qua non". Essential characteristics of logic can be realized by the use of natural language; symbolism is simply for elegance and more precisely for precision. Experience and learning seem to agree that there is no substance to logic, for no matter the appellation we give to different sorts of logic: informal logic, predicate logic, prepositional logic, deontic logic, modal logic, etc, every sort of logic concerns itself with forms. Etuk affirms and rightly too that "the central concern of logicians is always what information can be validly inferred from any given information.” (Oladipo, 2002) On this score then, the position of Alonzo Church seems shaky. He states that:

The difference of a formalized language from a natural language lies not in any matter of principle, but in 
the degree of completeness that has been attained in the laying down of explicit syntactical and semantical rules and the extent to which vagueness and uncertainties have been removed from them. (Alonzo, 1951)

The fact (and the truth) is that natural language has a kind of plasticity that allows everything that need be said to be said, irrespective of the fact that this natural language be illogical. The connection between logic and language, as logic is an essential aspect of every culture shows and gives credence to the existence of logic in Igbo-African world. Little wonder, Momoh stressed that "the competent individual in nay society is logical". Not even in Europe is an individual subjected to logical calculi to show he is logical. Not even every philosopher understands without ado the mathematical logic.

It is only in error will one deny Igbo-African world of logic; when logic is seen as abstracted and formalized whole which it is not in entirety. It will do logic great disservice and lead to intellectual disquiet. Think of the Igbo-African appreciation of time and status; our rendition of these concepts suggests that there will be IgboAfrican logic, for only such logic will ground Igbo-African theory of knowledge. Logical ability restricted to formal truth in logic is without doubt a monopoly of trained logicians not even trained philosophers. Notwithstanding the adjective one would use in qualifying the kind of logic inherent in natural language call it emotive, traditional or affective, the fact remains that there is logic in natural language. So it is very absurd to hold that there is no logic in Igbo world or else one would be saying that the Igbo lack sense of reason which is fool-hardy to hold. Uduma argues:

To argue that because, in traditional Africa, the people did not set out the rules of inference and replacement to test the validity of arguments, then they were not logical is tantamount to arguing that because our forefathers were not trained in mathematics and the physical sciences, they had no idea of engineering. (Unah, 1998)

We cannot rightly hold that the Igbo have no logic or sense of logic for they have always made inference in life, and have always seen nature as intelligible for they have organized reality through history. We think the philosophers of Africa and in Africa should wake up and work on the systematization of Igbo thought and logic, and even raise it to the level of mathematical logic so as to make use of logical calculi. Now let us examine the natural language of the Igbo and unveil the logic therein.

\section{Logic in Igbo Language and World}

Learning and experience show that the Igbo are logical in their thought and behaviour. There is no gainsaying the fact that the Igbo know and recognize the laws of thought i.e. law of non-contradiction, excluded middle, etc. These principles are seen in operation when the Igbo make attempts to resolve problems of the day; you will observe that their understanding corresponds with their experience which no doubt crops from their ontology; for as a being is, so it acts (agere sequitur esse). As Locke said, we assume same for the Igbo that: God has given "the Igbo man" a mind that can reason without being instructed in methods of syllogizing; the understanding is not taught to reason by these rules; it has a native faculty to perceive the coherence of its ideas and can range them right without any such perplexing repetitions. (Locke, 1984)

The Igbo know that what is, and what is not is not; that there is no middle course for something cannot be black and white at the same time for it entails inconsistencies. The Igbo know that:

Ichowairienu, ichowaudo Ichowairataazu, itinyeididen'ukpoo Ichowaiwetaihe di nauju, ichowannunuonumpi. Ichowairatankita, ichowaokpukpuanu. If you want to climb, you look for rope; If you want to ensare some fish, you fasten worms; If you want to get something inside the trunk of a tree, you look for a bird with pointed peak; If you want to invite a dog, look for a piece of bone.

Do you know that the Igbo apply and employ some logic in naming events and things? Think about this:

\section{Bridge-akwammiri (ogwe) Upstair-uloelu Bungalow-ulo ala Tarred road-okporouzooyibo.}

So there is no time the Igbo set out time to pattern their thought in the formal structure of syllogistic logic or engage in prepositional logic, and yet they think logically; and we do not think any other people does so. The Igbo know that if all men before us have died that all men today will sometime die. Their logic is more than implicative.

They say 
Oyiakwaawuarumaraonwaya-He who baths with his clothes on should know himself Were ilegiguoezegionu-Use your tongue to count your teeth.

Agwoanyigburuodimkpirikpi one?-The snake we killed, how many pieces are there?

You can see these sentences are implicative, inferential and moreso suggestive.

Likewise in statements like

Agadinwanyi da ndaadaugboroatoaguaihe o bun'ukpaonu—-If an old woman falls down thrice the content of her basket should be counted.

Here in context, it is left for the hearer to draw conclusion, the promises are there, it is like enthymeme in Western logic. Nze comments:

Exercises in argumentation are a form of mental training, and a well-trained mind is useful for learning about the world and for living well. It will not be surprising then if logic has a different purpose for people; it may be regarded as a tool (organon) of philosophy and science, a means for making unknown things known through known premises. (Nze, 1998)

It is logic, we mean practical logic that assist the Igbo in scientifically being able to discriminate between truth and falsehood; and head on to ensure that there is proper peace and harmony. Igbo logic is culture-bound. Little wonder Okolo, C. B. attests:

... the African reasons not with abstract premises but with difficulties he encounter in real life, in other words, his reasoning is a reaction, the result of coming face to face with the facts of life. This is thought, therefore thinking is social, it occurs in a given cultural milieu (Okolo, 1987).

So logic considers language; and Nzeadds, but only so far as differences of expression in language are the embodiment of differences or type in the process of thought (Nze, 1998).

\section{Conclusion}

We purposefully set up the topic of our paper in question form; in order to examine some of the objections some philosophers have raised not that we really asked about the possibility of Igbo logic for there had always been one. Igbo logic grounds Igbo language; it is not only natural, pragmatic and juridicial, it is equally aimed at resolving challenges and problems cropping up in Igbo-African existential sphere. That it is known to be natural logic does not cage it, it can as well be developed to become formalized so as to make use of logical calculi. From all we have said there is no doubt that Igbo logic is both deductive and inductive.

\section{References}

Alonzo, C. (1951). The Need for Abstract Entities in Semantic Analysis. Proceedings of the American Academy of Arts and Science, 180, 106.

Alston, W. P. (1964). Philosophy of Language (p. 23). New York: Prentice Hall.

Bronstein, D. J., Krikorian, Y. H., \& Wiener, P. P. (1947). Basic Problems of Philosophy (p. 194). New York: Prentice Hall Inc.

Carroll, J. B. (Ed.) (1971). Language, Thought and Reality (p. 240). Cambridge: The MIT Press.

Enyimba, M. (2003). The Role and Significance of Logic in African Thought System (p. 17). B.A. Dissertation, Calabar: UNICAL (University of Calabar).

Etuk, U. (2002). The Possibility of African Logic. In O. Oladipo (Ed.), The Third Way in African Philosophy (Essays in Honour of Wiredu, K.) (pp. 102, 110). Ibadan: Hope Publications.

Feyerabend, P. (1975). Against Method (p. 52). London: Verso.

Hallen, B. (1977). Horton Robin on Critical Philosophy and Traditional Thought. Second Order. African Journal of Philosophy, 1, 84-85.

Halymn, D. W. (1984). Metaphysics (p. 43). Cambridge: Cambridge University Press.

Ijiomah, C. O. (1995). Modern Logic: A Systematic Approach to the Study of Logic (p. 11). Owerri: AP Publications.

Lidell-Scott (1968). Greek English Lexicon. Oxford: Clarendon Press.

Locke, J. (1984). An Essay Concerning Human Understanding (Vol. 11). Everyman’s Library, 265.

Mellone, S. H. (1902). An Introductory Textbook of Logic. London: William Blackwood \& Sons, 6.

Momoh, C. S. (Ed.) (2003). The Substance of African Philosophy. Auchi: African Philosophy Project Publications, 174. 
Nze, C. B. (1998). Uncovering Logic in Igbo Language and Thought. WAJOPS, 1, 131-142.

Ogugua, P. I. (2003) The Epistemological Conditions of African Understanding (A Study of the Functions of Symbolism in Igbo Systems of Thought). Ph.D. Thesis, Nsukka, Enugu State: Department of Philosophy, University of Nigeria.

Okolo, C. B. (1987). What Is African Philosophy? Enugu: Freeman’s Press.

Onyewuenyi, I. C. (1983). A Philosophical Reappraisal of African Belief in Reincarantion. International Philosophical Quarterly, 22, 163.

Unah, O. (1998). Logic as an Element of Culture. In Unah, J. (Ed.), Metaphysics, Phenomenology and African Philosophy (pp. 374-391). Ibadan: Hope Publications.

Webster, N. (1980) Webster's New Twentieth Century Dictionary of English Language (2nd ed.). London: William Collins Publication.

Werkmeister, W. H. (1968) An Introduction to Critical Thinking and Logic (p. 3). London: Clarendon Press. 